\title{
Технічне та технологічне забезпечення цифрових технологій у рослинництві
}

\author{
О.Д. Деркач ${ }^{1}$, Т. Шестаков, Д.І. Крутоус \\ Дніпровський державний аграрно-економічний університет, \\ (м. Дніпро, Україна) email: ${ }^{1}$ Derkach_dsau@i.ua
}

\begin{abstract}
Наведено огляд технічного та технологічного забезпечення технологій цифрового землеробства світових провідних виробників та огляд українських онлайн платформ у сфері точного землеробства. На прикладі програмного забезпечення AFS Software показано приклад реалізації навчального процесу здобувачів вищої освіти із залученням агропідприємства.
\end{abstract}

Ключові слова: агропідприємства, технології цифрового землеробства, онлайн платформи, навчальний процес.

Актуальність роботи. Ще у “Програмі виробництва технічних комплексів, машин і обладнання для АПК на 1998-2005рр" було вказано, що «...щорічна технологічна потреба сільського господарства України в зернозбиральних комбайнах складає близько 9 тис. машин, у тому числі 3,6 тис. класу 8 - 10 кг зернової маси в секунду. Закупка в таких кількостях зернозбиральних комбайнів закордонного виробництва нереальна, тому що вимагає значних витрат, еквівалентних 40 \% вартості врожаю зернових культур.» Сьогодні ж кількість зернозбиральних комбайнів в Україні у порівнянні з 2009 роком зменшилася з $57435[1,5]$ до близько 27000 одиниць у 2016 [2], а зараз ця кількість, очевидно, ще менша. При цьому продуктивність праці в аграрному секторі України за останні 18 років зросла в 12,5 раз [3] і подальший його розвиток невпинно буде супроводжуватися впровадженням сучасних технологій землеробства, які характеризуються застосуванням дистанційних програм діагностування та контролю стану техніки, використанням автопілотованої техніки, безпілотних літальних апаратів (БПЛА), відповідних програм (софтів), що супроводжують та підвищують ефрективність ведення землеробства. Це забезпечує: удосконалення енерго- та грунтоощадних технологій вирощування с.-г. культур, скорочення витрат на використання техніки, тотальний контроль і облік стану ґрунтів, посівів, всіх видів ресурсів, виробництва і т. д. При цьому слід зауважити, що Україна фактично не має власного виробництва зернозбиральних комбайнів, має обмежене виробництво тракторів, однак проблем із забезпеченням аграрного сектору новою технікою сьогодні немає. Більше того, Україна сьогодні перебуває у п'ятірці світових лідерів за темпами впровадження технологій цифрового землеробства (ЦЗ), перебуваючи поряд із США, Канадою, Австралією, Новою Зеландією. Завдяки цим технологіям агропідприємства нашої держави сьогодні конкурують між собою у площині собівартості вирощеної продукції.

3 цього випливає, що в світі глобалізації науково-технічного прогресу власне виробництво, наприклад, складної техніки, не завжди гарантовано вирішує проблеми забезпечення країни технікою, про що інформативно говорить скріншот 3 соцмереж, де українські фірми допомагали сусідній країні, яка має власне виробництво зернозбиральних комбайнів, технікою (рис.1). Очевидно, що закладам вищої освіти необхідно впроваджувати в освітній процес вивчення технологій точного (Precision Farming) та ЦЗ (Digital Farming), однак це неможливо зробити без участі в цьому процесі передових аграрних підприємств, які вже активно впроваджують їх у своєму виробництві.

Огляд софтів для ведення технологій цифрового і точного землеробства. Впровадження технологій ЦЗ вводить новий етап виробництва с.-г. продукції, пов'язаний з використанням роботів, автоматизованих та інтелектуальних систем управління і, відповідно, з'являються нові терміни, пов'язані з цим типом виробництва. Сьогодні відомі визначення точного та «розумного землеробства» (їх можна знайти у вільному доступі на теренах інтернету), впровадження яких дозволяє збирати значну кількість різноманітних даних виробництва в реальному часі, обробляти і зберігати їх. Цифрове ж землеробство інтегрує обидві концепції точного та розумного землеробства. Його можна визначити як «послідовне застосування методів точного та розумного землеробства, внутрішніх та зовнішніх взаємозв'язків господарства, а також використання як 
веб-платформ, що містять дані, так і аналізу великих даних" - згідно з визначенням DLG (Hімецького сільськогосподарського товариства). Ми коротко розглянемо технічне та технолоічне забезпечення технологій ЦЗ та точного землеробства.

2. $8 \times 1.9$

Помогите найти комбайны на услуги по уборке пшеницы братьям в Республике Беларусь. Буду признателен за контакты.

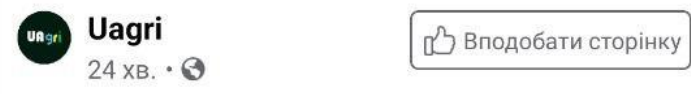

Нужны комбайны на уборку пшеницы в Гомельской обл, Беларусь.

3500 га, нагрузка 500 га на комбайн.

... Переглянути більше

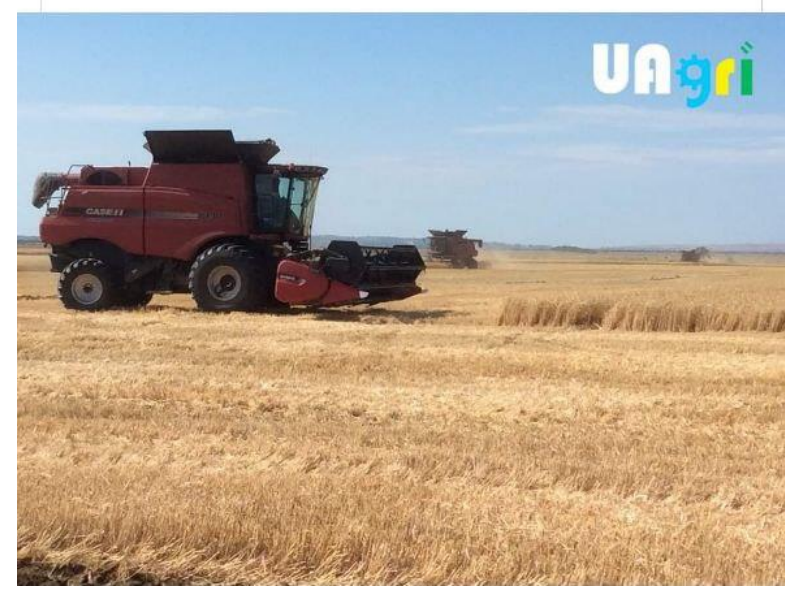

Рис.1. Скріншот із соцмереж з проханням до українських аграріїв допомогти в збиранні пшениці в Гомельській області

Сьогодні, середні і крупні агрохолдинги використвують мінімально необхідну кількість техніки, людських, матеріальних та фрінансових ресурсів, однак виконують значний обсяг робіт із великою ефективністю. Цьому сприяє використання надійної і високопродуктивної зарубіжної с.-г. техніки, оснащеної елементами інтелектуальних фрункцій. Наприклад, основний парк машин у агропідприємстві ТОВ «Агро КМР», з яким співпрацює наш університет, має такі машини: комбайни Case IH 9240 - 6 одиниць, укомплектовані жатками МасDon FD-75 (ширина захвату 13,7 м), трактори Case IH MX 340/380 - 4 од., Case IH STX 600 Quadtrac - 1 од., бункери-перевантажувачі Kinze1350 та Kinze-850, об'ємом, відповідно 60 та 27 м³, обприскувачі John Deere 4930 і 4030, посівні комплекси Horsch Maestro SW (36 рядків, 18 метрів ширина захвату) - 2 од., Horsch ATD 9,35 - 2 од. $€$ також допоміжна техніка (телескопічні навантажувачі, автомобілі). Підприємство має 12 власних метеостанцій, площа землекористування - 15000 га. Основні технології вирощування с.-г. культур: No-Till, Strip-Till. Кількість працюючих 53. Технології ЦЗ у даному підприємстві підтримуються програмним забезпеченням AFS Software, дисплеями Trimble GFX-750, Trimble TMX-2050, приймачами NAV-900 та іншим обладнанням інформаційного супроводу. Процес виробництва, планування та контроль, аналіз виробничої діяльності підприємства здійснюється в платформі Cropio (рис.2). В результаті, затрати на виробництво продукції та логістика максимально оптимізовані і знижені до обґрунтованого мінімуму. Всі роботи відбуваються у стислі терміни. Детальніше про підприємство та процес збирання ранніх зернових колосових культур можна подивитися на відеороликах, скачавши QR-коди, подані нижче:
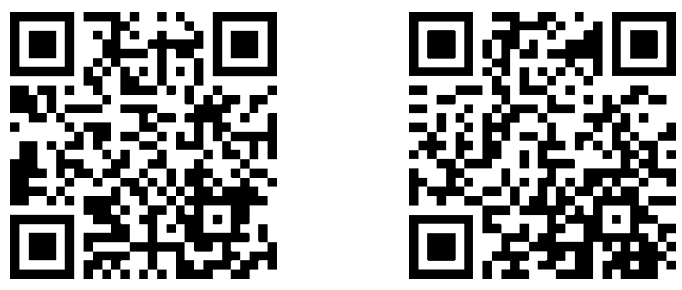

В платформі Cropio зберігається і накопичується необхідна інформація історії полів та використання техніки на них, погодні дані, терміни виконання операцій та затрати, результати, підраховується сума ефективних температур, зібрана з метеостанцій підприємства і т.д. Зрозуміло, що доступ до неї можна отримати в будь-якій точці світу, де $є$ інтернет, а, отже, є можливість неперервного керування процесами.

Аналогічні цифрові платформи розробили практично всі великі виробники с.-г. техніки: John Deere (JD Link, AMS), CNH (AFS Software), CLAAS (Telematics). При цьому, слід зауважити, що є цифррові платформи-аналоги. Так, AFS Software (рис. 3) повністю аналогічна платфрормі PLM Software. Особливість цифрових платформ полягає в тому, що виробничі дані, зібрані в процесі експлуатації техніки передаються і відображаються вже в програмі цифрової платформи, що дозволяє здійснювати управління та контроль виробничого процесу, прийняття рішень в реальному часі. Передачу даних можна здійснити як за допомогою флеш-носія, так і через інтернет або мобільний зв'язок. Які дані передаються: карти-завдання на виконання технологічної операції, карти врожайності, показники швидкості агрегату в полі, часи виконання роботи, простої, кількість витраченого пального (питома і загальна), технічний стан техніки і багато іншого. Слід зауважити, що кількість параметрів постійно збільшується, так як технології ЦЗ є динамічними системами і софти постійно оновлюються декілька разів на рік.
ISSN 2311-1828

http://enm.khntusg.com.ua
Інженерія природокористування, 2020, №2(16), с. 120 - 127

Engineering of nature management, 2020, \#2(16), p. 120 - 127 


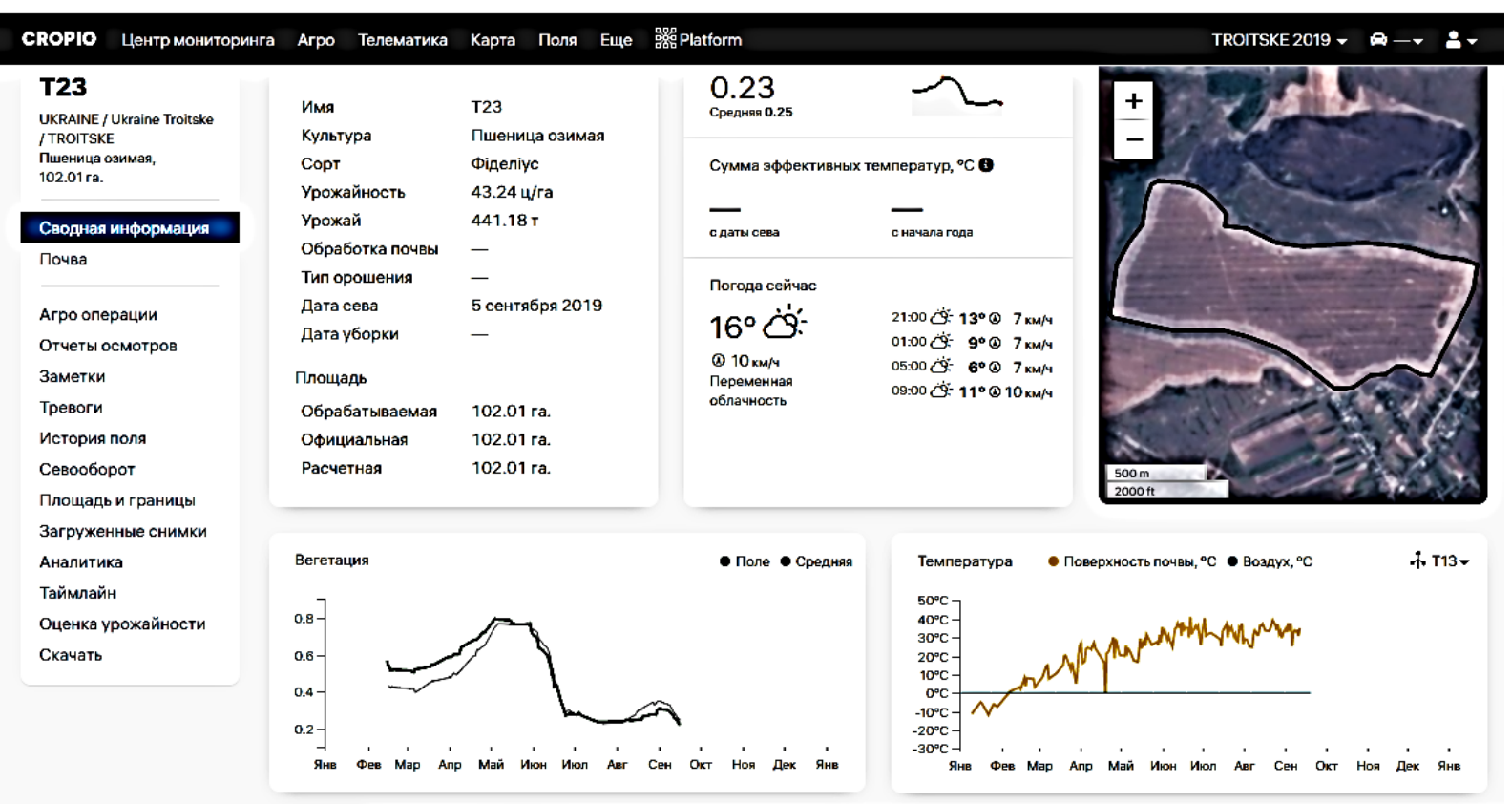

Рис.2. Фрагмент інтерфейсу цифрової платформи Cropio, що використовується в ТОВ «Агро КМР».

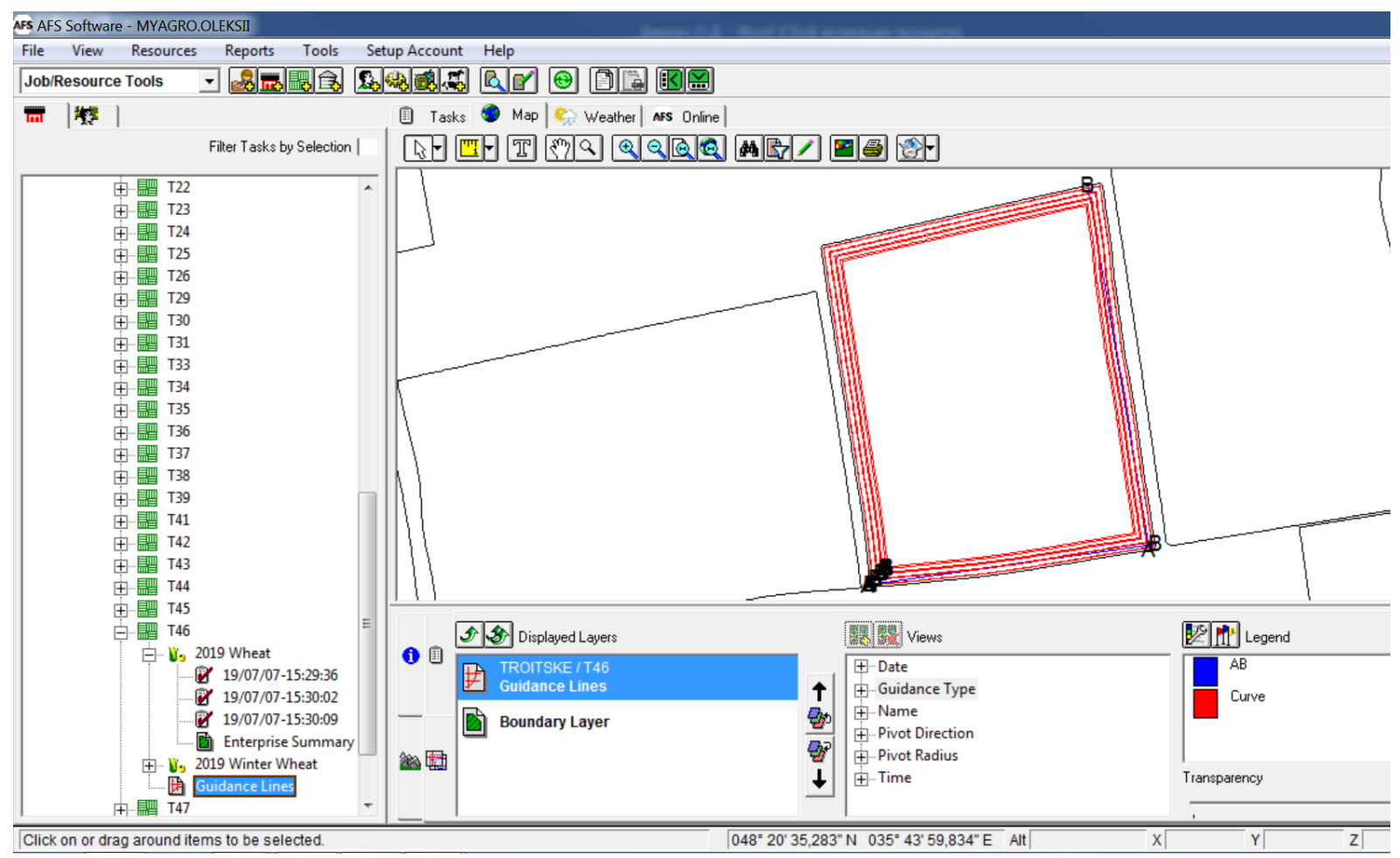

Рис.3. Скріншот інтерфейсу цифрової платформи AFS Software при побудові ліній ведення техніки на полі Т 46 в ТОВ «Агро КМР».

Зісканувавши QR-код, поданий нижче, можемо побачити на відео, що агрегат Case IH Magnum 380 + Horcsh Maestro 36.5, із завантаженою картою диференційованого посіву соняшника здійснює перехід з однієї зони висіву (75 тис./га) в зону меншої норми висіву (70 тис./га) і знову 
повертається в зону максимального висіву. Це можна бачити у правому верхньому кутку монітора Trimble TMX 2050.

Кількість підприємств, що застосовують технології ЦЗ сьогодні стало зростає. Великі агрохолдинги мають економічну можливість використовувати вищевказані цифрові платформи, бо мають на це кошти.

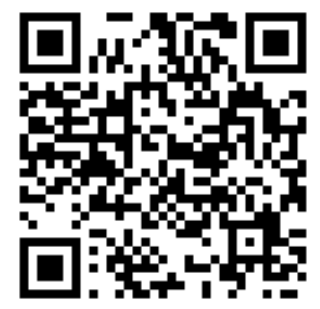

Наприклад, монітор TMX 2050 (рис. 4), по суті - це високотехнологічний багатофункціональний комп'ютер з інтерактивним екраном, коштує близько 205 тис. грн., щорічна підписка на підтримку фрункціонування платформи AFS коливається від 750 до 1100 євро та є й інші витрати, пов'язані із використанням ТЦЗ. Тому, більш складні та інформативні цифрові платфрорми впроваджуються у великих агрохолдингах, а менш функціональні, а отже і дешевші - в середніх та малих фермерських господарствах. Проте, дорогі технології і обладнання з часом стають також доступні до ширшого кола користувачів. I завдання коледжів та університетів - навчити здобувачів вищої освіти користуватися всіма наявними сьогодні на ринку послуг цифровими продуктами.
Приклад. Наведемо один приклад оптимізації технологічного процесу хімічного захисту рослин з використанням цифрової платформи PLM. Так, в одному з підприємств за допомогою БПЛА здійснено оперативний контроль стану посівів ріпаку озимого і виявлено, що тривалі дощі в певних ділянках поля знищили посіви.

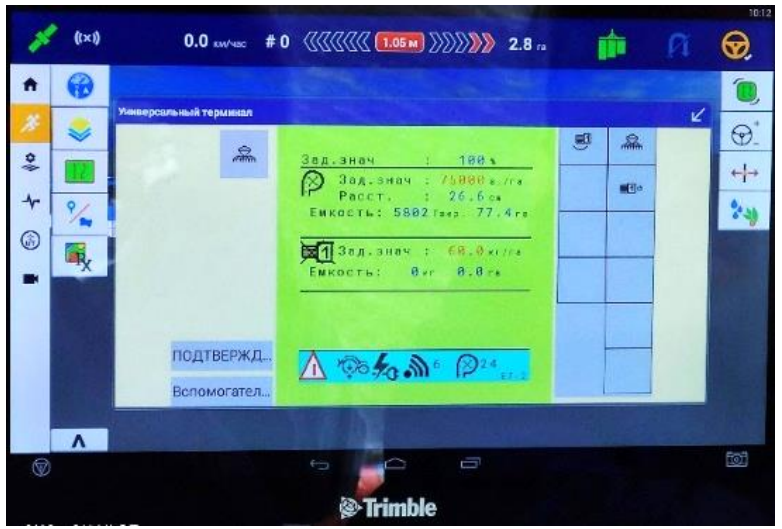

Рис. 4. Загальний вигляд монітора ТМХ 2050 виробництва Trimble.

Розміри та координати цих ділянок були внесені з показників БПЛА в цифрову карту, яка була завантажена в бортовий комп'ютер обприскувача. Агроном прийняв рішення: здійснювати обробку засобами захисту рослин (33Р) з нормою 150 л/га (синій колір) і взагалі не здійснювати обробку (норма 0 л/га - червоний колір) у разі проходу оприскувача над знищеними водою ділянками (рис. 5).

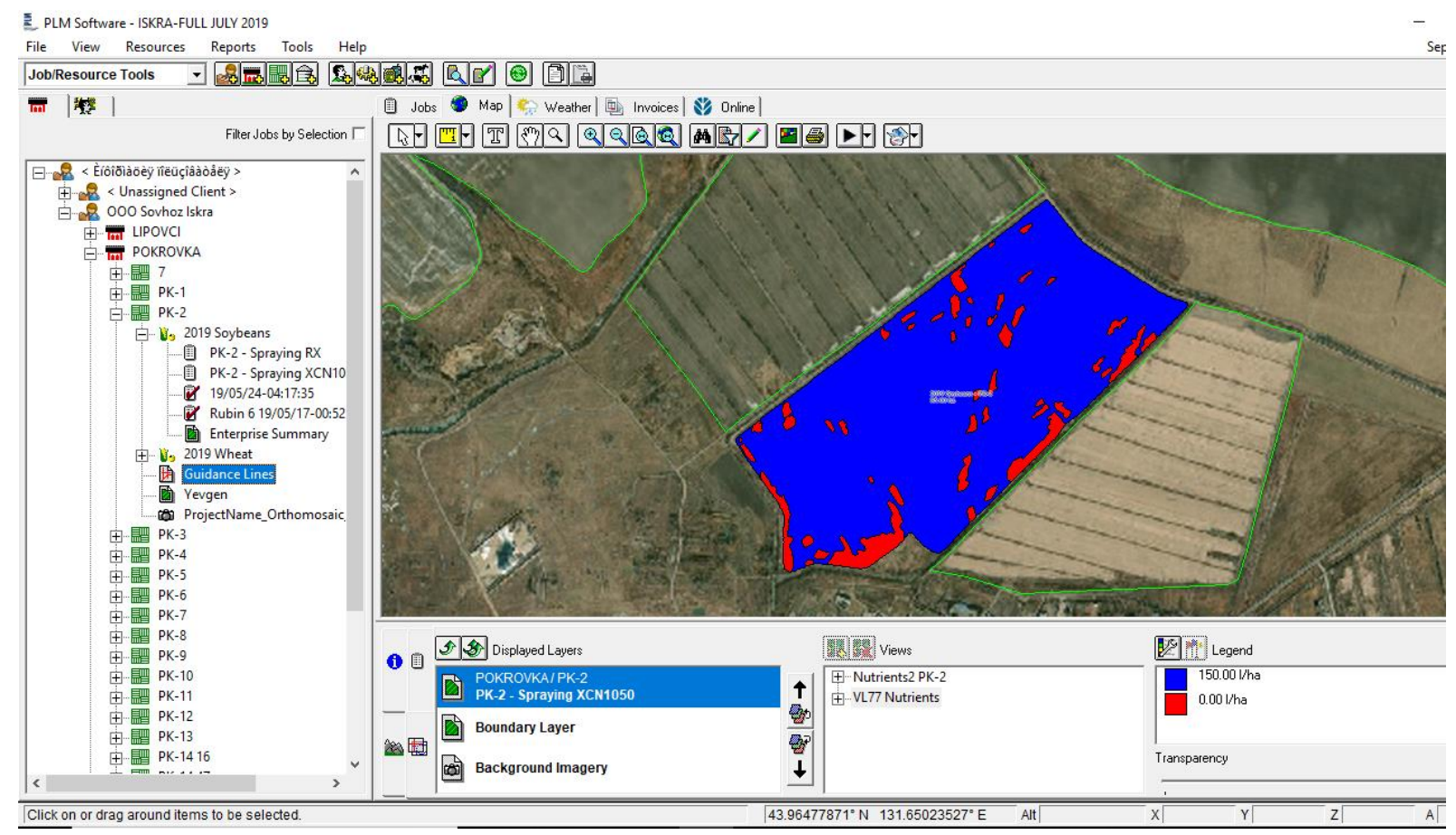

Рис. 5. Оперативна карта для диференційного внесення 33Р.

ISSN 2311-1828

http://enm.khntusg.com.ua
Інженерія природокористування, 2020, №2(16), с. 120 - 127

Engineering of nature management, 2020, \#2(16), p. 120 - 127 
Що це дало підприємству в даному випадку? Відключення розпилювачів на обприскувачі у разі проходу над ділянкою поля, де посіви знищені водою, забезпечило зниження витрат З3Р на $9,5 \%$. Економію склало не тільки зменшення об'єму робочого розчину, а і витрати на транспортування та приготування 33Р. Тобто, зменшилася енергоємність, а отже і собівартість даної технологічної операції. Аналогічним чином, проводяться коригування на всіх стадіях виробництва: на основних і допоміжних операціях, у процесі виробничих узгоджень (наприклад, узгодження за кратністю ширини захвату агрегатів, їх продуктивністю і багато іншого).

Відео про описану виробничу ситуацію можна подивитися, зіскануваши цей QR-код

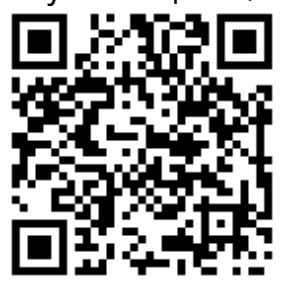

Середні та малі фермерські господарства починають впроваджувати окремі елементи точного землеробства, використовуючи значно простіші навігаційні продукти. I хоч тут не йдеться про цифровізацію виробництва, однак впровадження систем паралельного водіння, ведення виробничих процесів у спеціально адаптованому для с.-г. виробництва програмному забезпеченні також дозволяє підвищити ефективність виробництва, а отже - знизити собівартість продукції. Одним із виробників, які пропонують універсальне навігаційне обладнання є підприємство «ГеоМетр Україна» (м. Дніпро), які пропонують недороге і спрощене у користуванні обладнання для впровадження технологій паралельного водіння, вимірювання площі полів, метеостанції та онлайн платформу «Агропрофріль» (рис.6) для планування і фіксації показників використання техніки та управління іншими ресурсами виробництва [4].

Українські виробники онлайн платформ сьогодні також пропонують нові програми для управління виробничою діяльністю $[6,7]$, однак їх не можна назвати цифровими, так як вони не забезпечують передачу телематичних даних, зібраних з техніки. Так, вітчизняний продукт AgroOnline (рис.7) можна віднести до програм, які підтримують технології точного землеробства, однак ще не має функціоналу, які впроваджували б цифровізацію виробництва.

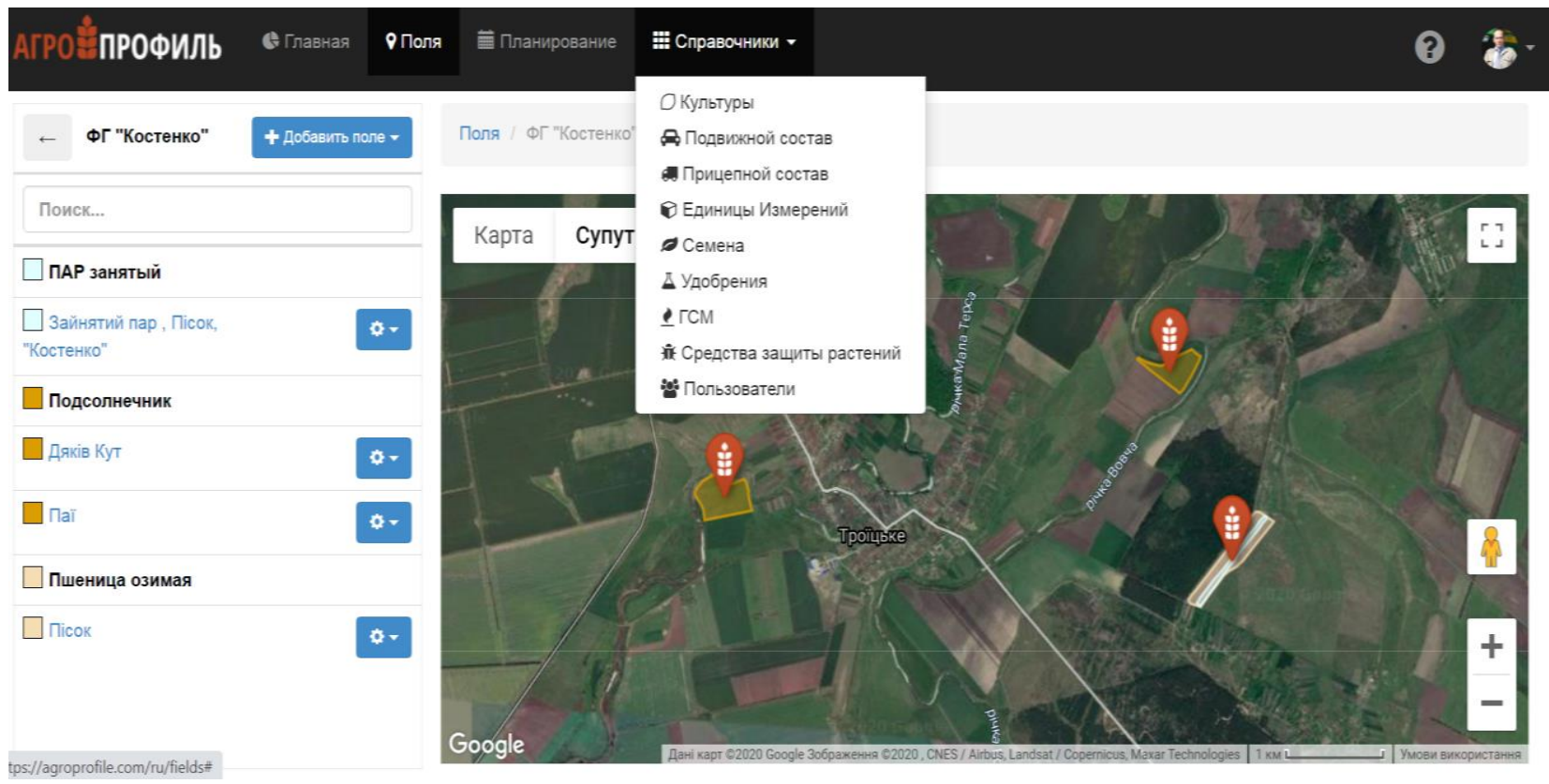

Рис.6. Загальний вигляд онлайн платформи «Агропрофріль».

Реалізація в освітньому процесі. Виникає питання, як і чому навчати здобувачів вищої освіти спеціальності 208 «Агроінженерія» в розрізі дисципліни «Машиновикористання в рослинництві»? Очевидно, що університети не можуть забезпечити матеріальну складову (техніка, обладнання для технологій ЦЗ), а інформаційний блок без практичної складової не дасть ефективного результату. І якщо заклади вищої освіти не зможуть впровадити програми навчання технологіям ЦЗ - цю функцію повністю на себе переберуть фрірми-виробники цих продуктів. 


\section{O.D. Derkach, T. Shestakov, D.I. Krutous}

\section{МАПА АНАЛІЗІВ ГРУНТТУ}

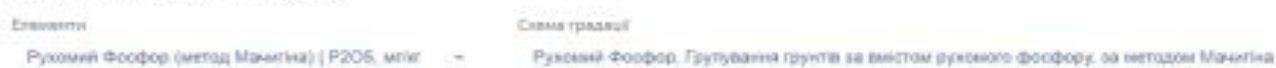

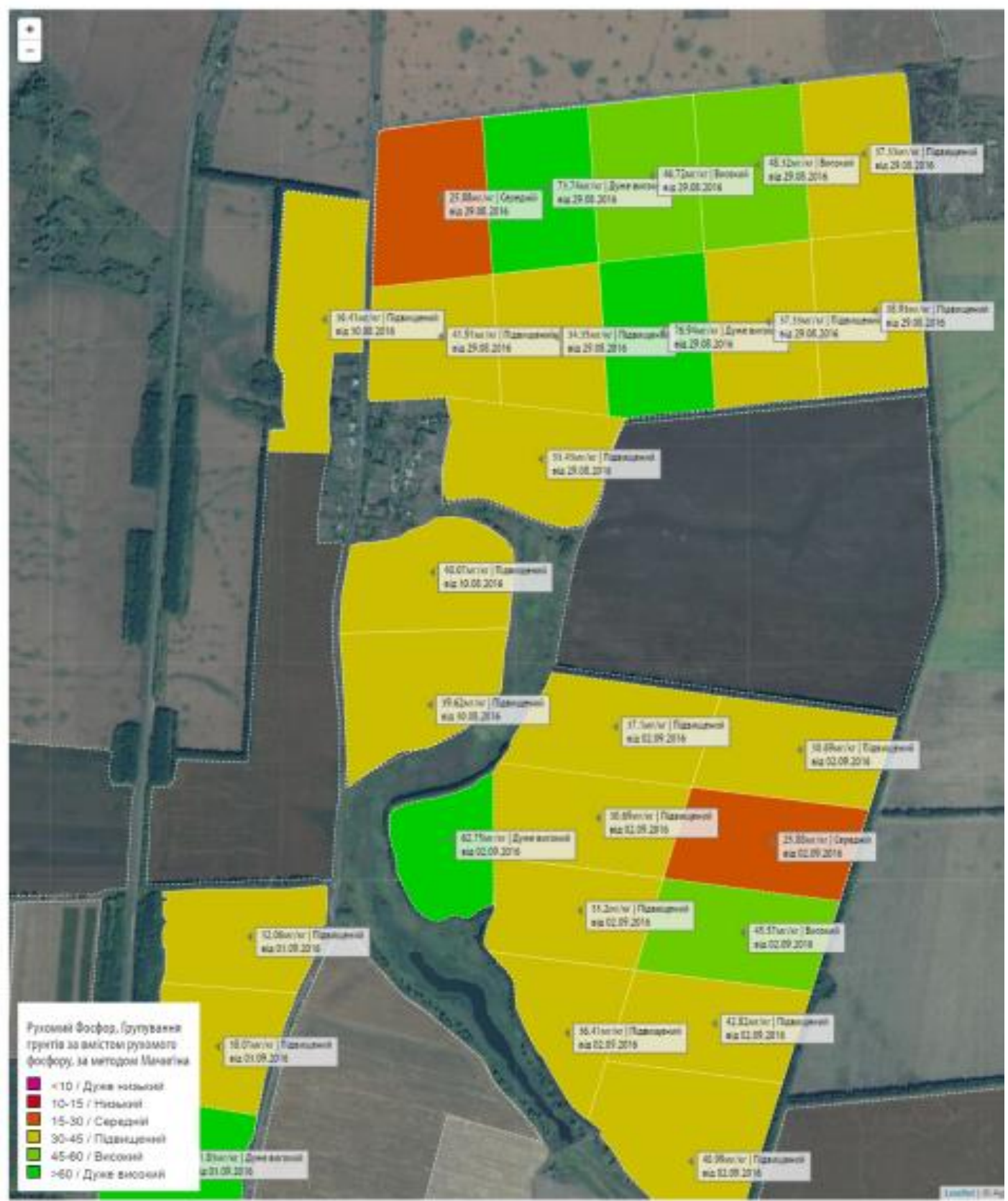

Рис. 7. Загальний вигляд платформи АгроOnline

В принципі, сьогодні це вже відбувається, адже дилери створюють так звані Academy: Claas Academy, Агротек Academy та ін., де навчання відбувається силами самих підприємств без залучення фахівців з університетів. Не секрет, що викладачі не володіють сучасними знаннями в області технологій ЦЗ і продовжують навчати студентів на застарілій техніці і, відповідно, застарілим технологіям. Слід відзначити, що викладати в університетах технології Ц3 в автономній формі не має сенсу, бо тут необхідна ціла низка умов:

- обладнання, як вже говорилося вище, надзвичайно дороге;
Інженерія природокористування, 2020, №2(16), с. 120 - 127

Engineering of nature management, 2020, \#2(16), p. 120 - 127 
- без прямого зв'язку з виробництвом навчити здобувачів вищої освіти цим технологіями неможливо, бо без практичного впровадження він не побачить результату свої роботи.

Що сьогодні зроблено у цьому напрямку, наприклад, на кафедрі експлуатації машинно-тракторного парку ДДАЕУ:

- з 2019 року реалізується експериментальний проект з підготовки фахівців у галузі технологій Ц3, із залученням викладача з Olds College (Канада), використанням платформи AFS Trimble та практичних заняттях на території ТОВ «Агро КМР» Дніпропетровської області.

- залучені в навчальний процес IT-фрахівці та агрономи цього агропідприємства допомагають виконувати практичні роботи (спочатку це побудова карт-завдань, а потім робота з ними в полі) викладачам та здобувачам вищої освіти, при цьому практичні заняття $€$ реальними виробничими завданнями, що підвищує зацікавленість та відповідальність учасників навчального процесу.

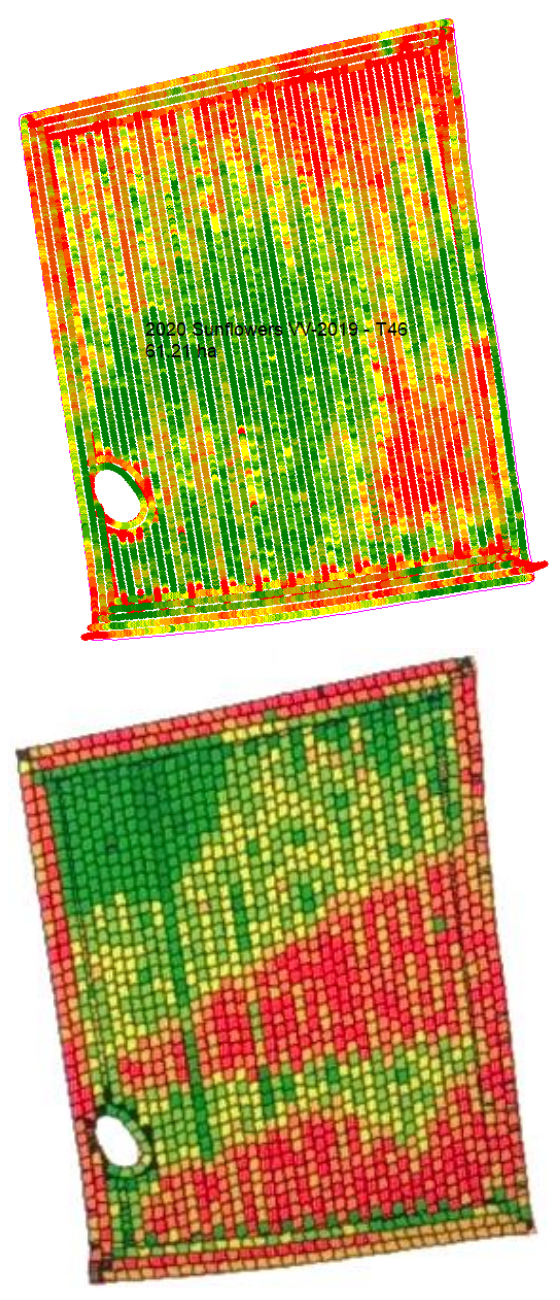

Рис.8. Диференційована карта виконаної сівби та карта врожайності соняшника, зроблені та оброблені студентами в середовищі AFS Software на полі T46 ТОВ «Агро КМР»
Наприклад, студенти після вивчення цифрової платформи AFS Software, встановленої в ДДАЕУ, розробили карту завдання диференційованого посіву, завантажили карту в бортовий комп'ютер посівного агрегату та провели разом 3 механізаторами ТОВ «Агро КМР» диференційовану сівбу соняшника, отримали карту дифпосіву (рис.8). Вже восени, після збирання, отримали карту врожайності соняшника. Тепер можна, знаючи історію поля, технологію вирощування, співставити отримані результати та провести оптимізацію виробництва, що підвищити його ефективність.

\section{Висновки.}

Для реалізації в агропідприємствах технологій цифрового землеробства, необхідно мати техніку, обладнану спеціальними датчиками та системами позиціонування, обладнання - монітори та програмне забезпечення.

Великі виробники сільськогосподарської техніки мають власні продукти, призначені для роботи в технологіях цифрового землеробства: John Deere - AMS), CNH - AFS Software, CLAAS - Telematics.

Українські виробники пропонують значно простіші продукти, що придатні для застосування в точному землеробстві: AgroOnline, Агропрофріль.

Впровадження вивчення технологій цифрового землеробства можливе лише за умови виконання практичної складової в умовах реального виробництва на підприємствах, що застосовують технології цифрового землеробства у своїй виробничій діяльності.

\section{Література:}

1. Аналіз ринку зернозбиральних комбайнів України. Пропозиція - Головний журнал з питань агробізнесу [Електронний ресурс]. Режим доступу: https://propozitsiya.com/ua/analiz-rinkuzernozbiralnih-kombayniv-ukrayini

2. Надточій О. Аналіз динаміки комбайнового ринку України / О. Надточій, Л. Тітова, І. Роговський // Техніко-технологічні аспекти розвитку та випробування нової техніки і технологій для сільського господарства України. - 2016. Вип. 20. - С. 254-262.

3. Потенціал розвитку ринку техніки АПК. [Електронний ресурс]. Режим доступу: http://agrobusiness.com.ua/agro/ekonomichnyi-hektar/item/ 10881-potentsial-rozvytku-rynku-tekhniky-apk.html. Останнє звернення: 23.11.2019 р.

4. ГеоМетр Україна. [Електронний ресурс]. Режим доступу: https://shop.gpsgeometer.com.

5. Войтюк Д. та ін. Аналіз ринку зернозбиральних комбайнів України // Пропозиція - Головний журнал з питань агробізнесу. 2010. [Електронний peсурс]. Режим доступу: https://propozitsiya.com/ ua/analiz-rinku-zernozbiralnih-kombayniv-ukrayini 
6. Виробник рішень для точного землеробства. [Електронний ресурс]. Режим доступу: https://skokagro.com

7. Комплексна система управління аграрним бізнесом. [Електронний ресурс]. Режим доступу: https://agro-online.com

\section{References:}

1. Analiz rinku zernozbiral'nikh kombajni v Ukrayini (2020) Propoziczi ya - Golovnij zhurnal z pitan' agrobi'znesu. Available at: https://propozitsiya.com/ua/analiz-rinku-zernozbiralnih-kombayniv-ukrayini (Accessed: 2 August 2020).

2. Nadtochij, O., Titova, L. and Rogovskij, I. (2016) 'Analiz dinamiki kombajnovogo rinku Ukrayini', Tekhniko-tekhnologichni aspekti rozvitku ta viprobuvannya novoyi tekhniki i tekhnologij dlya silskogo gospodarstva Ukrayini, (20), pp. 254-262.
3. Kernasyuk, Y. (2018) Potenczial rozvitku rinku tekhniki APK, Agro-business.com.ua. Available at: http://agro-business.com.ua/agro/ekonomichnyi-hektar/item/10881-potentsial-rozvytku-rynkutekhniky-apk.html.

4. GeoMetr Ukrayina (2020). Available at: https://shop.gpsgeometer.com.

5. Voitiuk, D. et al. (2010) 'Analiz rynku zernozbyralnykh kombainiv Ukrainy', Propozytsiia Holovnyi zhurnal z pytan ahrobiznesu. Available at: https://propozitsiya.com/ua/analiz-rinku-zernozbiralnih-kombayniv-ukrayini.

6. Precision Farming Solutions Manufacturer (2020) skokagro.com. Available at: https://skokagro.com.

7. 'Kompleksna sistema upravlinnya agrarnim biznesom' (2020) agro-online.com. Available at: https://agro-online.com.

\section{Аннотация}

\section{Техническое и технологическое обеспечение цифровых технологий в растениеводстве}

\section{А.Д. Деркач, Т. Шестаков, Д.И. Крутоус}

Дан обзор техничекого и технологического обеспечения технологий цифрового земледелия ведущих мировых производителей, а также обзор украинских онлайн-платформ в сфере точного земледелия. На примере AFS Software показана реализация учебного процесса студентов с привлечением сельскохозяйственного предприятия.

Ключевые слова: агропредприятия, технологии цифрового земледелия, онлайн платформы, учебный процесс.

\section{Abstract}

\section{Technical and technological support of digital technologies in crop production}

\section{O.D. Derkach, T. Shestakov, D.I. Krutous}

An overview of technical and technological support of digital farming technologies of the world's leading manufacturers and an overview of Ukrainian online platforms in the field of precision farming are given. For example of AFS Software shows an example of the implementation of the educational process of students with the involvement of an agricultural enterprise.

Keywords: agricultural enterprises, digital agriculture technologies, online platforms, educational process.

\section{Бібліографрічне посилання/ Bibliography citation: Harvard}

Derkach, O. D., Shestakov, T. and Krutous, D. I. (2020) 'Technical and technological support of digital technologies in crop production', Engineering of nature management, (2(16), pp. 120 - 127.

Подано до редакції / Received: 02.08.2020 